\title{
Energy Recovery from Municipal Solid Waste by Briquetting Process: Evaluation of Physical and Combustion Properties of the Fuel
}

\author{
Anita Shrestha ${ }^{1}$ and Ramesh M. Singh ${ }^{2}$ \\ ${ }^{1}$ Central Department of Environmental Science, Tribhuvan University, Kirtipur, Kathmandu \\ ${ }^{2}$ Center for Energy and Environment, Kathmandu \\ e-mail:asanita.shrestha@gmail.com
}

\begin{abstract}
This study presents an experimental production of solid waste briquettes from municipal solid waste by screw extrusion technology and piston press technology. Combustible matters present in municipal solid wastes like paper, plastic and biomass (represented by rice husk) were pro- cessed using grinders and shredders and then densified. Two varieties of Refuse derived fuel were subjected to heat (around $300{ }^{\circ} \mathrm{C}$ ) in Screw Extrusion machine while seven varieties of Selective fuel in the composition $0-70 \%$ lignite and $5-30 \%$ polyethylene by weight were densified at a constant pressure of 3.12 tons $/ \mathrm{cm}^{2}$ at room temperature in piston press briquetting machine. Lime was added to one variety to capture emissions during fuel combustion. The production and analysis of the fuel briquettes were carried out according to Japanese Industrial Standards (JIS 8811, 8812) in the Biomass laboratory of NAST at Khumaltar. It was observed that addition of waste plastic improves fuel quality of low grade coal (lignite). High temperature and high pressure is required for briquetting the mixture of plastic and paper waste. The produced fuel briquettes might be suitable for use in industrial boilers and brick kilns but suitable control measures should be applied to capture harmful emissions.
\end{abstract}

Key words: paper, plastic, refuse derived fuel, screw extruder briquetting, selective fuel

\section{Introduction}

Energy is a vital input for development and an essential ingredient for the survival of mankind. Two of the major energy issues today are that of energy security and environmental implication of fossil fuel consumption. Municipal solid waste management is another huge challenge. In developing countries like Nepal, the issues of energy security and municipal solid waste management are more prominent. Nepal relies mainly on traditional sources ( 87 percent) of energy while the imported petroleum products, coal, hydroelectricity and renewable and other forms of energy meet over 12 percent of the total energy demand of the country. All the petroleum products consumed in Nepal are imported from India or overseas in the refined form for direct consumption (WECS 2010). There is no denying that a resource poor country like Nepal, is bound to face a severe energy crisis in the near future because of its over dependence on imported fuel. 
On the other hand, the issue of municipal solid waste (MSW) management is receiving major environmental concerns worldwide. In Nepal, this problem is more acute especially in the industrial and urban areas due to the lack of resources, infrastructures, effective solid waste management alternatives (techniques), trained manpower and research backup for solid waste transformation into commercial products. While the volume of waste ending up in landfill is ever increasing, the space available for dumping is limited and decreasing.

Recent study shows plastic and paper comprise about 17 percent of the municipal solid waste in Kathmandu valley (SWMRMC 2008). Plastic waste, mainly polyethylene bags, in the MSW has high energy content, as much as kerosene. Such a high energy content material, which is all imported using the valuable foreign currency, should not be dumped in the landfill. It should be recycled and then used for heat recovery (Heejoon 2006).

Briquetting technology is one of the simple technologies practiced for making biomass-based fuels including wastes like milled paper, plastic and other combustible wastes. The municipal waste of Kathmandu can be best recovered/reused by transformation into solid waste fuel briquettes either in the form of Refuse Derived Fuel (RDF), a compressed form of waste paper, plastics, wood chips and other combustible materials, or in the form of Selective fuel, a blend of combustible organic component such as plastics of MSW with low grade coal like lignite. In this light, waste-to-energy conversion would be an economical and eco friendly way for addressing both the issues of waste management and energy shortage, both at the same time.

\section{Methodology}

The raw materials used for the briquette production were collected at domestic level (news paper and plastic bags) and commercial sources (rice husk and L3: Lele coal-Singh 2001). The production and laboratory analysis of the fuel briquettes were carried out according to Japanese Industrial Standards (JIS 8811 and JIS 8812) in the Biomass laboratory of the Faculty of Technology of NAST at Khumaltar.
Production process: The raw materials were reduced to particle size appropriate for briquetting with the help of grinders and shredders to then proceed with densification. Refuse derived fuel (RDF) were made as cylindrical briquettes with a hole through the centre from the mixture of-i) polyethylene (35 percent) and paper (65 percent) and ii) rice husk (50 percent), polyethylene (25 percent), paper (20 percent) and lime (5 percent) by applying heat of $300{ }^{\circ} \mathrm{C}$ from screw extrusion machine. The tablet type briquettes, i.e., selective fuel (SF) were produced from varying proportions of lignite $100-70 \%$ by weight and polyethylene $0-30 \%$ by weight at a constant pressure of 3.12 tons $/ \mathrm{cm}^{2}$ for ten seconds at room temperature, in piston press briquetting machine to yield tablets of 5 grams. The screw extrusion briquetting machine was fabricated for cylindrical briquette production while tablet type briquettes were made using the simple piston press available at Nepal Academy of Science and Technology laboratory.

Laboratory analysis: The proximate analysis ( moisture content, ash content, volatile matter content, fixed carbon content) was conducted following JIS 8812 and the calorific value of the raw materials ( lignite, polyethylene, rice husk and paper) were determined in College of Applied Sciences - Nepal according to IP-12 standard using Calibrated Bomb Calorimeter. The breaking strength of the fuel was tested using Maruto scale for breaking strength determination. The performance analysis of the produced briquette was tested using the standard water-boiling test (Water boiling test Version 1.5, Shell Foundation) in induced air fanned stove ( Bayu pankhi chulo) operating at 6 to12 $\mathrm{V}$, available at NAST.

Flue gas analysis: The flue gas from the combustion of the fuel briquettes were evaluated using the Bacharach Oil Burner Smoke Scale (qualitative analysis) while Carbon Monoxide (CO ppm) and percentage of Nitrogen Oxides, Sulphur Oxides and Carbon Dioxide emission during fuel combustion were analyzed using Hodaka Flue Gas analyzer HT-2300 (Gas Analyzer) and accessories, Fluke $\mathrm{CO}$ meter and Kitagawa Aspirating pump with tubes (quantitative analysis). Besides, the particulate matters, $\mathrm{PM}_{10}$ and $\mathrm{PM}_{2.5}$, were measured during the Water boiling test using Haz Dust EPA M-500. 


\section{Results and Discussion}

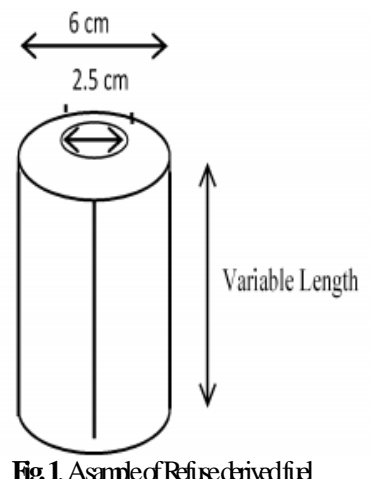

Fig 1 . Asampleof Refisedrivedfied

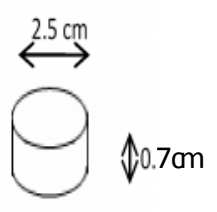

Fig 2 Asample of Slectivefud

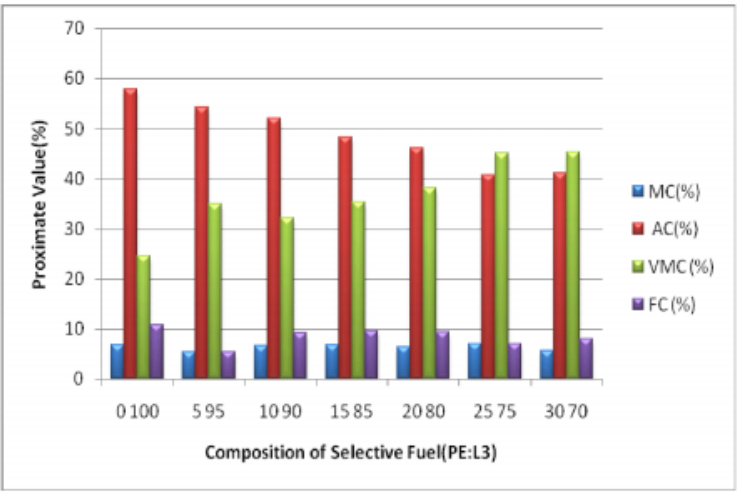

Fig.4. Proximate analysis of seven compositions of Selective fuel

Calorific value: The calorific value $(\mathrm{CV})$ of $\mathrm{RDF}_{1}$ is comparable to the currently imported Indian coal (NAST, 2007). Similarly, CV of 25:75 is not so far from that of Imported Indian coal. This implies that fuel quality of low grade coals like L-3 can be improved by introduction of high volatile matters like polyethylene.

The calorific value of the lignite and polyethylene briquette shows increasing trend for calorific value along the increase of polyethylene in the briquette. (fig. 5)

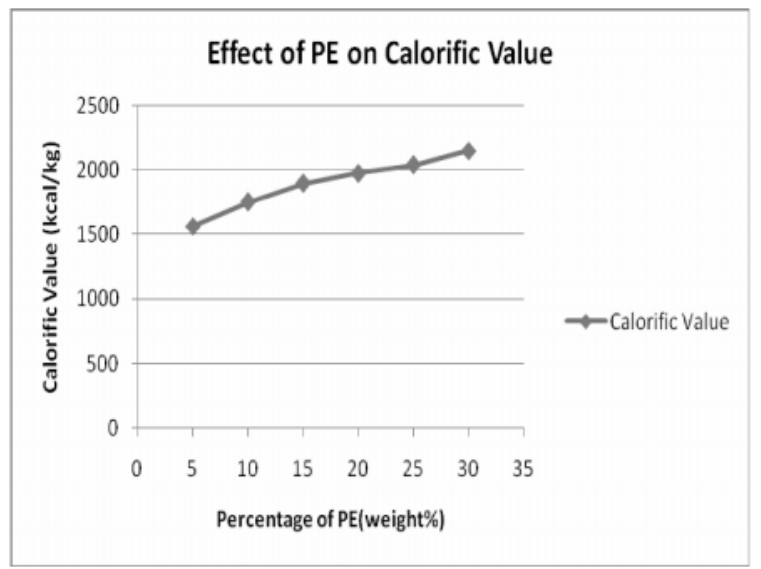

Fig.5. Effect of polyethylene on Calorific value

Breaking strength: Experiments showed that briquettes with plastic manufactured at low temperature fall apart easily. Screw extruded briquettes $\left(\sim 300^{\circ} \mathrm{C}\right)$ were stronger than those briquetted at room temperature $\left(27^{\circ} \mathrm{C}\right)$ in piston press. At room temperature, the breaking strength (BS) of the briquette gradually increases as the percentage of polyethylene 
(PE) in the briquette increases (fig. 6). Initially the breaking strength increases slowly with the increase of PE content. As the PE content increases the BS increases, which after wards tends to remain constant.

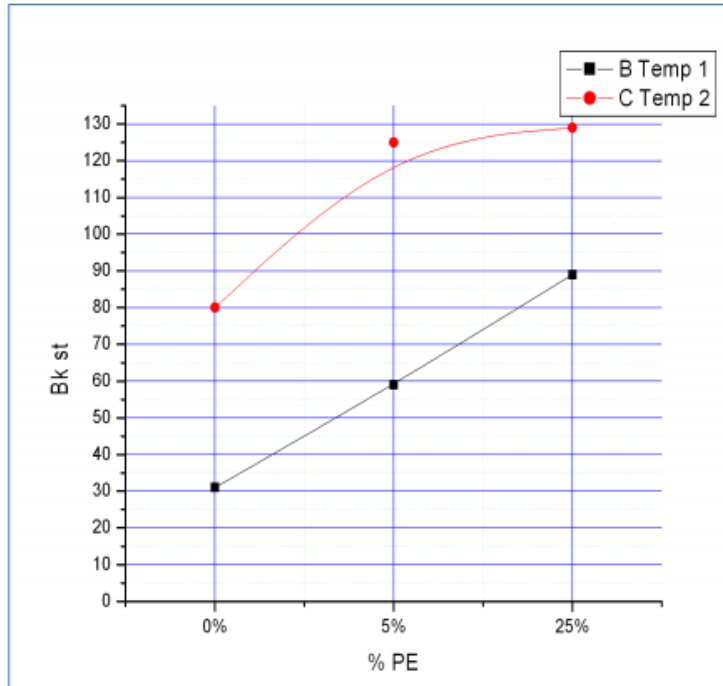

Fig. 6. Breaking strength versus Temperature

Performance analysis: The industrial application of the fuel was analyzed for steam generation by water boiling test. Preliminary water boiling test in air induced fanned stove using RDFs and SF (25:75) showed thermal efficiency fairly more than $20-25 \%$, obtained for fuel wood or rice husk.

Flue gas emissions: Among the fuel briquettes, Smoke index test was performed for a sample of $\operatorname{RDF}(65: 35)$ and SF (25:75). The smoke number for the fuel briquettes is below the harmful limits in sufficient air supply. This indicates the fuel is suitable for industries that use blowers. As for emission tests, results show that the amount of $\mathrm{NO}_{2}$ and $\mathrm{CO}_{2}$ emitted in the flue gas is observed very less. $\mathrm{CO}$ emission is high in the flue gas but because the measurement was done in the combustion zone, it will be relatively higher than in the ambient air. Addition of 5\% lime in the RDF showed significant lowering in the $\mathrm{CO}$ concentration in the flue gas.

The PM were examined at the combustion zone in the absence of an emission hood and hence both of the fuel sample types-RDF and SF exceeded the permissible range of National Indoor Air Quality Standards for $\mathrm{PM}<10$ for 24 hour exposure.

Results of Proximate analysis, Calorific value, Breaking strength and Performance analysis, show good fuel characteristics of briquettes produced from wastes (paper, plastic and rice husk). Moreover, it is observed that addition of waste plastic improves fuel quality of low grade coal. The produced fuel briquettes might be suitable for use in industrial boilers, brick kilns, etc but suitable control measures should be applied to capture harmful emissions. This Waste-to-energy Conversion option not only extends the life of landfill but also provide an alternative energy resource by utilizing unused waste products.

\section{Acknowledgements}

The author wishes to acknowledge Nepal Academy of Science and Technology for the technical support during this dissertation research work.

\section{References}

Heejoon, K., R.M. Singh and L. Tianji. 2006. Ecofuel - A blend of coal with plastics. Journal of World Review of Science, Technology and Sustainable Development 3(1): 49-57.

JIS M8811, 1976. Japanese Industrial Standards- Methods for Sampling and Determination of Total Moisture and Adherent Moisture of Coal and Coke .Japanese Standards Association, Japan.

JIS M8812. 1984. Japanese Industrial Standards- Methods for Proximate Analysis of Coal and Coke. Japanese Standards Association, Japan.

NAST, 2007. Biomass Database. Biomass Laboratory, Faculty of Technology, National Academy of Science and Technology (NAST), Khumaltar, Lalitpur, Nepal.

Singh, R.M., M. Toshihiko, M. Kamide, K. Taniguchi and K. Deguchi. 2001. Biobriquettes - An Alternative Fuel for Domestic and Industrial applications. Nepal Journal of Science and Technology 3: 105-114.

SWMRMC. 2008. A Diagnostic Report on State of Solid Waste Management in Municipalities of Nepal. Solid Waste Management and Resource Mobilisation Centre (SWMRMC), Lalitpur, Kathmandu, Nepal, pp. 5-16.

WECS. 2010. Energy Sector Synopsis Report 2010. Water and Energy Commission Secretariat, Kathmandu, Nepal, pp.13, 81-95. 